ISSN 1678-3921

Journal homepage: www.embrapa.br/pab

For manuscript submission and journal contents, access: www.scielo.br/pab

\section{Pruning, training system, and climate conditions for the perennial cultivation of physalis}

\begin{abstract}
The objective of this work was to evaluate the effect of pruning and training system type on the agronomic performance of the perennial cultivation of physalis (Physalis peruviana), in high-altitude tropical and humid temperate regions in Southeastern Brazil. The experiments were carried out in the municipalities of Diamantina (humid temperate climate) and Couto de Magalhães de Minas (high-altitude tropical climate), both in the state of Minas Gerais, in two cycles (2017/2018 and 2018/2019). In the first cycle, two types of training system were evaluated, one with formation pruning to define the number of stems for espalier training and the other free (without pruning and espalier). In the second cycle, renewal pruning was evaluated in each training system. Physalis cultivation in regions with humid temperate climate and mild temperatures favors high yields and large fruits. The training system in espalier with formation pruning facilitates plant management and increases productivity. The viability of the perennial cultivation of physalis varies according to the climatic conditions of the cultivation site and to the training system adopted.
\end{abstract}

Index terms: Physalis peruviana, espalier, high-altitude tropical climate, humid temperate climate, training system.

\section{Poda, sistema de condução e condições climáticas para o cultivo perene de fisalis}

Resumo - O objetivo deste trabalho foi avaliar o efeito da poda e do tipo de sistema de condução sobre o desempenho agronômico do cultivo perene de fisalis (Physalis peruviana), em regiões de clima tropical de altitude e temperado úmido no Sudeste brasileiro. Os experimentos foram realizados nos municípios de Diamantina (clima temperado úmido) e Couto de Magalhães de Minas (clima tropical de altitude), ambos no estado de Minas Gerais, em dois ciclos (2017/2018 e 2018/2019). No primeiro ciclo, foram avaliados dois tipos de sistema de condução, um com poda de formação para definir o número de hastes para condução em espaldeira e outro livre (sem poda e espaldeira). No segundo ciclo, avaliou-se a poda de renovação em cada sistema de condução. O cultivo de fisalis em regiões de clima temperado úmido, com temperaturas amenas, favorece produções altas e frutos grandes. O sistema de condução em espaldeira com poda de formação facilita o manejo das plantas e aumenta a produtividade. A viabilidade do cultivo perene de fisalis varia de acordo com as condições climáticas do local de cultivo e o sistema de condução adotado.

Termos para indexação: Physalis peruviana, espaldeira, clima tropical de altitude, clima temperado úmido, sistema de condução. 


\section{Introduction}

Physalis (Physalis peruviana L.) is an exotic fruit, belonging to the Solanaceae family, with great value due to its attractive quality attributes for the national and international markets (Bolzan et al., 2011; Fischer et al., 2012, 2014). In Brazil, it has been included in the ranking of small fruits and, as of 2008, its commercial cultivation has been adapted to a wide temperature range, considering its ideal planting temperatures are between 15 and $25^{\circ} \mathrm{C}$ (Rufato et al., 2012; Rodrigues et al., 2014). In the country, the central and southern regions of the state of Minas Gerais are considered climatically suitable for the cultivation of physalis according to the agricultural zoning of climatic risks made by Aparecido et al. (2019). However, due to a reduced plant production and fruit quality when the species is cultivated for a prolonged time, physalis is only grown as an annual plant despite its perennial habit (Lima et al., 2012).

In order to increase plant time in the field while maintaining vigor, production and quality, some management practices can be adopted, such as pruning and different training systems. Pruning consists of reducing stems and the number of stem sprouts for the formation and conduction of the plant, in order to prevent stems from being overloaded by the mass of fruits, which can cause plants to tip or even break (Criollo et al., 2014; D'Angelo et al., 2017). In addition, pruned plants produce larger-sized fruits due to the smaller number of vegetative and reproductive drains, leading to a better distribution of photoassimilates (Moura et al., 2016).

Regarding the training system, physalis requires support, such as staking, as it is a shrub that can form a very dense stem. Several training systems have been tested for the cultivation of physalis, based on tomato (Lycopersicon esculentum Mill.) crops, and the most used in Brazil are the X and V systems, as well as the simple espalier system (Muniz et al., 2011).

Therefore, plant conduction and pruning management are recommended, as they facilitate plant management and improve fruit and canopy quality, allowing the cultivation of the same physalis plant for up to two years (Muniz et al., 2015a). However, the results on pruning management are variable depending on cultivation conditions and on the response of physalis to pruning for stem renewal. Moreover, there is no information aiming the perennial cultivation of this species under Brazilian conditions.

The objective of this work was evaluate the effect of pruning and training system type on the agronomic performance of the perennial cultivation of physalis, in high-altitude tropical and humid temperate regions in Southeastern Brazil.

\section{Materials and Methods}

The research was carried out under field conditions in two orchards, installed in two different sites in the state of Minas Gerais, Brazil. The first orchard was located in the municipality of Diamantina at Universidade Federal dos Vales do Jequitinhonha e Mucuri (18 $12^{\prime} 11^{\prime \prime S}$, $43^{\circ} 34^{\prime} 16^{\prime \prime} \mathrm{W}$, at $1,387 \mathrm{~m}$ altitude). The climate of the region is of the Cwb type, humid temperate, and the soil is classified as a Neossolo Quartzarênico, i.e., a Typic Quartzipsamment, according to Santos et al. (2018). The second orchard was located in the municipality of Couto de Magalhães de Minas (18 $04^{\prime} 15^{\prime \prime} \mathrm{S}, 43^{\circ} 28^{\prime} 15^{\prime \prime} \mathrm{W}$, at $726 \mathrm{~m}$ altitude). The climate of the region is of the Aw type, high-altitude tropical, characterized by a welldefined dry and rainy season, and the soil is classified as a Latossolo Vermelho-Amarelo distrófico, i.e., a Typic Haplorthox, according to Santos et al. (2018). The variations in temperature and precipitation registered for both municipalities, during the experimental period, from August 2017 to July 2019, is shown in Figures 1.

Physalis seedlings were produced from seeds extracted from ripe fruits, obtained from the experimental farm of Empresa de Pesquisa Agropecuária de Minas Gerais/Centro Tecnológico do Sul de Minas, located in the municipality of Maria da Fé, in the south of Minas Gerais. Seedlings were grown in $120 \mathrm{~mL}$ tubes containing the Bioplant commercial substrate (Bioplant Agrícola Ltda., Nova Ponte, MG, Brazil), in a greenhouse, where they were micro-sprinkler irrigated, with a flow rate of $1.2 \mathrm{~L} \mathrm{~h}^{-1}$, three times a day for $10 \mathrm{~min}$. Fifty days after seed sowing, when the seedlings had between three to four pairs of leaves and a well-formed root system, they were transplanted simultaneously to the field in both evaluated sites. In this way, all management practices adopted for physalis cultivation were carried out in the same way and at the same time in both locations.

Before planting, soil sample analysis showed: $1.1 \mathrm{dag} \mathrm{kg}^{-1}$ soil organic matter, $5.2 \mathrm{pH}_{\mathrm{H} 2 \mathrm{O}}, 1.6 \mathrm{mg} \mathrm{dm}^{-3}$

Pesq. agropec. bras., Brasília, v.56, e01850, 2021

DOI: 10.1590/S1678-3921.pab2021.v56.01850 
P, $22.1 \mathrm{mg} \mathrm{dm}^{-3} \mathrm{~K}, 0.6 \mathrm{cmol}_{\mathrm{c}} \mathrm{dm}^{-3} \mathrm{Ca}, 0.2 \mathrm{cmol}_{\mathrm{c}} \mathrm{dm}^{-3}$ $\mathrm{Mg}, 0.6 \mathrm{cmol}_{\mathrm{c}} \mathrm{dm}^{-3} \mathrm{Al}, 3.7 \mathrm{cmol}_{\mathrm{c}} \mathrm{dm}^{-3} \mathrm{H}+\mathrm{Al}$, base saturation of $19 \%, 830 \mathrm{~g} \mathrm{~kg}^{-1}$ sand, $100 \mathrm{~g} \mathrm{~kg}^{-1}$ clay, and $70 \mathrm{~g} \mathrm{~kg}^{-1}$ silt for the Typic Quartzipsamment; and
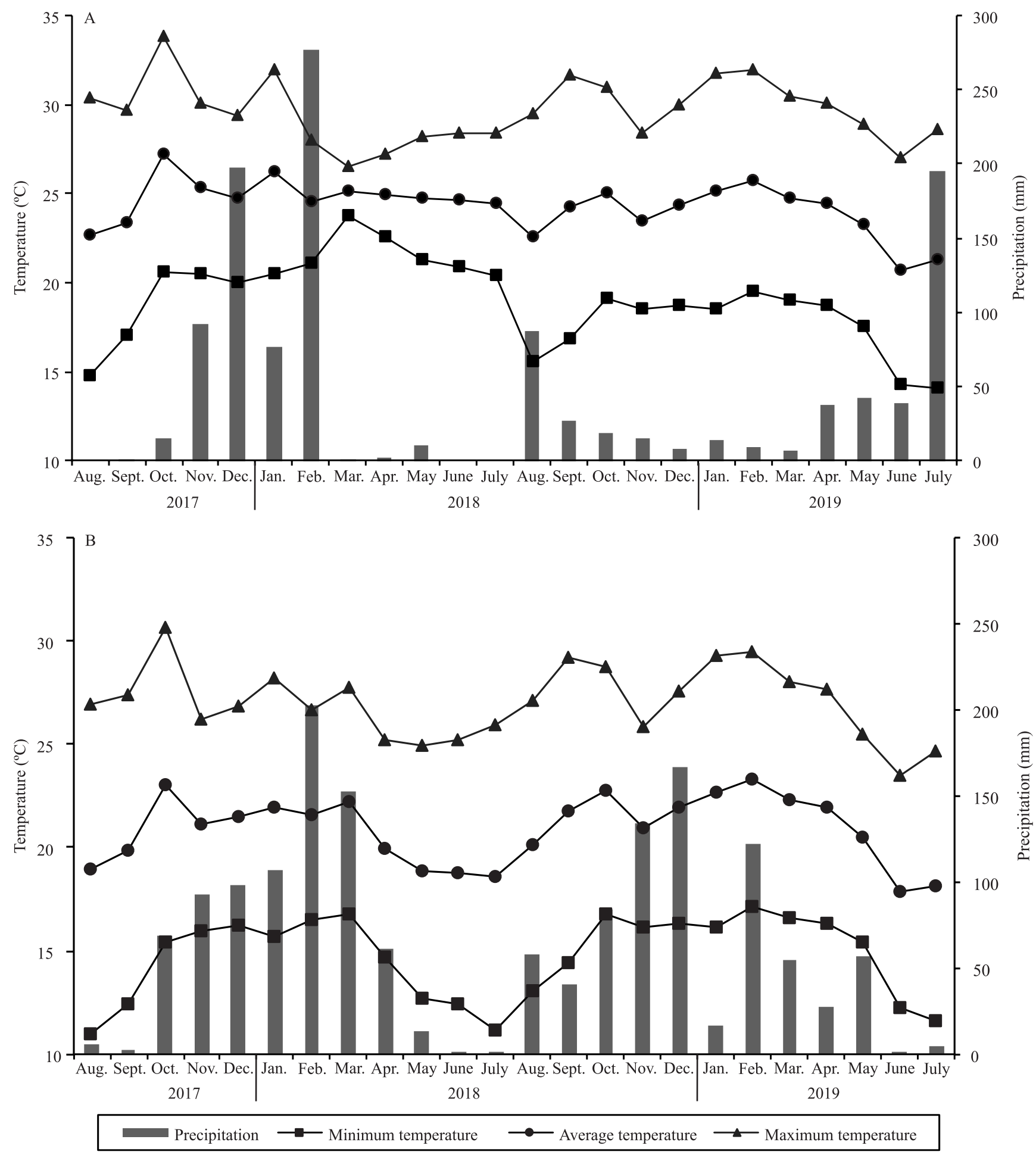

Figure 1. Monthly data on minimum, average, and maximum temperature, as well as on precipitation, recorded in the municipality of Couto de Magalhães de Minas (A) and of Diamantina (B), in the state of Minas Gerais, Brazil, during two crop cycles of physalis (Physalis peruviana). Source: Agritempo (2019). 
0.4 dag kg-1 soil organic matter, $5.1 \mathrm{pH}_{\mathrm{H} 2 \mathrm{O}}, 1.8 \mathrm{mg} \mathrm{dm}^{-3}$ $\mathrm{P}, 40.7 \mathrm{mg} \mathrm{dm}^{-3} \mathrm{~K}, 1.0 \mathrm{cmol}_{\mathrm{c}} \mathrm{dm}^{-3} \mathrm{Ca}, 0.3 \mathrm{cmol}_{\mathrm{c}} \mathrm{dm}^{-3} \mathrm{Mg}$, $0.5 \mathrm{cmol}_{\mathrm{c}} \mathrm{dm}^{-3} \mathrm{Al}, 3.7 \mathrm{cmol}_{\mathrm{c}} \mathrm{dm}^{-3} \mathrm{H}+\mathrm{Al}$, base saturation of $28 \%, 600 \mathrm{~g} \mathrm{~kg}^{-1}$ sand, $270 \mathrm{~g} \mathrm{~kg}^{-1}$ clay, and $130 \mathrm{~g} \mathrm{~kg}^{-1}$ silt for the Typic Haplorthox. The concentrations of $\mathrm{P}$ and $\mathrm{K}$ were extracted by Mehlich-1 and of $\mathrm{Ca}$ and $\mathrm{Mg}$, by $\mathrm{KCl} 1 \mathrm{~mol} \mathrm{~L}^{-1}$. Soil correction was carried out 60 days before the seedlings were planted, by applying dolomitic limestone to raise base saturation to $67 \%$ (Braga Neto et al., 2019).

The experimental area was prepared by opening furrows at $0.5 \mathrm{~m}$ depth and with $0.5 \mathrm{~m}$ width, to which $1.0 \mathrm{~L}$ bovine manure was added per linear meter. Fertilization was carried out following the recommendation for the cultivation of physalis in Brazil (Rufato et al., 2012), using $80 \mathrm{~kg} \mathrm{ha}^{-1} \mathrm{~N}, 150$ $\mathrm{kg} \mathrm{ha}^{-1} \mathrm{P}_{2} \mathrm{O}_{5}$, and $100 \mathrm{~kg} \mathrm{ha}^{-1} \mathrm{~K}_{2} \mathrm{O}$, whose sources were urea, simple superphosphate, and potassium chloride, respectively; each quantity was divided into three applications, at the time of planting, at 60 days, and at 90 days after planting. A spacing of $0.7 \mathrm{~m}$ between plants and of $2.0 \mathrm{~m}$ between rows was adopted, with a density of 7,142 plants per hectare.

In the first evaluated cycle (2017/2018), in both sites, plants were conducted using a completely randomized design, in two training systems, with 12 replicates and five plants per $200 \mathrm{~m}^{2}$ plot in each site. The types of training system evaluated were: formation pruning for espalier training and free. In the espalier system, two parallel wires were installed at 0.5 and $1.2 \mathrm{~m}$ from the ground. In this system, pruning was carried out to leave four main stems per plant, eliminating all sprouts from the plant base, at $0.40 \mathrm{~m}$ from the soil. The main stems were fixed to espalier wires, two conducted on each side, forming an X. In the free system, the plants were grown without pruning and espalier training, leaving all emitted stems and sprouts.

At the end of the first harvest, in July 2018, in the two training systems, half of the plants were pruned, at $0.10 \mathrm{~m}$ from the soil, to reduce all stems drastically and the other half was eliminated for planting of new seedlings. After pruning, when the plants began issuing new sprouts, in October 2018, new seedlings were planted. All management practices in the two orchards were the same as those adopted in the first production cycle.

In the second experimental year (2018/2019), the espalier and free systems were also used to conduct plants: new ones from the first cycle and plants subjected to renewal pruning in the second cycle. Therefore, the evaluation followed a $2 \times 2$ factorial arrangement, which consisted of two training systems (espalier and free) and of two cultivation cycles (perennial, plants subjected to renewal pruning; and annual, new plants of the first cycle), with six replicates and five plants per plot, in each site.

Weekly harvests were carried out in each plot individually, during the entire production period, from late summer to early winter, between February and June 2018 and 2019. All fruits were harvested with the calyx, which is required for physalis commercialization, when it presented a greenish-yellow color, adopted as an indicator of maturity.

The variables evaluated for agronomic performance were: fruit mass, determined by weighing the total mass of fruits with the calyx, divided by the total number of fruits of each plot; productivity, obtained by the average production per plant (ratio of mass to the number of plants in the plot), multiplied by the number of plants per hectare; and transverse diameter and longitudinal diameter of fruits without the calyx, both quantified using a $300 \mathrm{~mm}$ digital caliper (Digimess, São Paulo, SP, Brazil).

Statistical analyzes were performed independently for each production cycle, and all calculations were done using the Sisvar software (Ferreira, 2014). Initially, the agronomic performance data for each cultivation site were subjected to the analysis of variance, in order to verify the homogeneity of the residual variances, through the relationship between the largest and the smallest mean square of the residue, which must be less than 7 to proceed to the joint analysis (Pimentel-Gomes \& Garcia, 2002). In the first year (2017/2018), as this criterion was met, the joint analysis of variance of agronomic performance data was carried out in both environments for the training system of physalis plants. However, in the second year (2018/2019), data from each site were subjected to the analysis of variance separately, and the averages of training systems and perennial and annual cycles were compared by Tukey's test, at 5\% probability of error.

\section{Results and Discussion}

The cultivation environment was the only source of variation that influenced fruit productivity in the first 
year of production (2017/2018). A greater productivity of $13.5 \mathrm{Mg} \mathrm{ha}^{-1}$ was observed in the humid temperate climate in Diamantina, compared with that of 6.9 $\mathrm{Mg} \mathrm{ha}^{-1}$ in the high-altitude tropical climate in Couto de Magalhães de Minas (Table 1). The difference in productivity between the two cultivation sites can be related to the varying climatic conditions. In Couto de Magalhães de Minas (Figure 1 A), average temperatures were higher, between 24.6 and $26.4^{\circ} \mathrm{C}$, from February to June 2018, which influenced plant flowering. In Diamantina, temperatures were milder, between 21.6 and $18.8^{\circ} \mathrm{C}$ in the period of plant production (Figure $1 \mathrm{~B}$ ), favoring physalis cultivation and increasing productivity. At this site, the average temperatures are considered near the ideal conditions - between 15 and $25^{\circ} \mathrm{C}$ - for the cultivation of the species in Brazil (Rufato et al., 2012).

The fruit productivity in the two cultivation sites is higher than that of 2.98 to $6.0 \mathrm{Mg} \mathrm{ha}^{-1}$ reported for physalis in conditions of subtropical climate, at an average altitude of $916 \mathrm{~m}$ and temperature of $16^{\circ} \mathrm{C}$, under different training systems (Muniz et al., 2011). This difference is related to temperature and altitude, which have been identified as factors influencing plant growth and cycle length, as well as the productivity of cultivation site (Muniz et al., 2014).

Regarding fruit mass and diameter, there were significant differences between the cultivation sites

Table 1. Summary of the analysis of joint variance with its significance and averages for fruit productivity, mass, longitudinal diameter (LD), and transversal diameter (TD) of physalis (Physalis peruviana), in the 2017/2018 cycle, cultivated in the municipalities of Diamantina and Couto de Magalhães de Minas (CMM), in the state of Minas Gerais, Brazil.

\begin{tabular}{lcccc}
\hline $\begin{array}{l}\text { Source of } \\
\text { variation }\end{array}$ & \multicolumn{4}{c}{ Medium squares } \\
\cline { 2 - 5 } & $\begin{array}{c}\text { Productivity } \\
\left(\mathrm{Mg} \mathrm{ha}^{-1}\right)\end{array}$ & $\begin{array}{c}\text { Mass } \\
(\mathrm{g})\end{array}$ & $\begin{array}{c}\mathrm{LD} \\
(\mathrm{mm})\end{array}$ & $\begin{array}{c}\mathrm{TD} \\
(\mathrm{mm})\end{array}$ \\
\hline Training system (TS) & $11.38^{\text {ns }}$ & $0.03^{\mathrm{ns}}$ & $1.52^{\mathrm{ns}}$ & $0.66^{\mathrm{ns}}$ \\
Environment (E) & $529.16^{* *}$ & $5.40^{*}$ & $73.94^{* *}$ & $88.24^{* *}$ \\
Interaction (E x TS) & $8.05^{\text {ns }}$ & $0.07^{\mathrm{ns}}$ & $0.24^{\mathrm{ns}}$ & $0.28^{\text {ns }}$ \\
\hline Cultivation site & \multicolumn{4}{c}{ Average $^{(1)}$} \\
$\quad$ Diamantina & $13.54 \mathrm{~A}$ & $3.73 \mathrm{~A}$ & $17.15 \mathrm{~A}$ & $18.12 \mathrm{~A}$ \\
CMM & $6.90 \mathrm{~B}$ & $3.06 \mathrm{~B}$ & $14.66 \mathrm{~B}$ & $15.41 \mathrm{~B}$ \\
\hline CV $(\%)$ & 9.60 & 6.80 & 1.70 & 2.60 \\
\hline
\end{tabular}

(1)Means followed by equal letters, in the columns, do not differ by Tukey's test, at $5 \%$ probability. ${ }^{* *}$ and $*$ Significant at 1 and $5 \%$ probability,

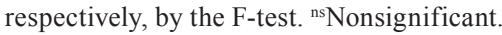

(Table 1). In Diamantina, higher caliber fruits were harvested, with a mass of $3.73 \mathrm{~g}$, a longitudinal diameter of $17.15 \mathrm{~mm}$, and a transversal diameter of $18.4 \mathrm{~mm}$. The difference in fruit size between both experimental sites can be attributed to climatic conditions, because plant growth and development are impaired under extreme cold (below $10^{\circ} \mathrm{C}$ ) or excessive heat (above $35^{\circ} \mathrm{C}$ ), which interfere in final fruit quality and decrease productivity (Muniz et al., 2015b). The results observed in the present study confirm that physalis development is better under cold climate conditions.

Despite the different productivities in the two studied sites, all fruits can be classified as class A because their mass ranged from 3 to $10 \mathrm{~g}$ and their diameter from 15 to $18 \mathrm{~mm}$. These values are recommended by Codex Alimentarius (2011), mainly for crops with climatic conditions similar to those of Diamantina, a site of higher productivity, providing a greater profitability to the producer.

The training system did not influence productivity and fruit quality in the first year of evaluation (Table 1). This result is probably related to the photoassimilate demand for plant growth, because, in the free system, without pruning, an average of ten stems grew per plant, while in the espalier system and formation pruning, only four main stems grew, limiting the amount of sprouts for fruit production.

Plant growth and the number of formed stems are strongly influenced by climatic elements, such as temperature, light, and altitude, besides soil conditions (Muniz et al., 2014; Braga Neto et al., 2019). Therefore, the thesis of climate influence on plant size explains the greater vegetative growth of the plants in the second cycle in the high-altitude tropical climate in Couto de Magalhães de Minas (Table 2). In this site, physalis growth was favored by the occurrence of higher temperatures, lower altitude, and higher nutrient concentrations in the soil, despite the adoption of the same fertilization management as in the first cycle.

In crops under conditions similar to those of Couto de Magalhães de Minas, it is recommended that producers adopt a greater spacing between plants and pruning management to reduce the number of main stems and of side shoots, in order to promote a greater light and aeration for the plants. In the cultivation in Diamantina, the lower plant vegetative growth may 
be related to the increase in UV radiation caused by the elevation in altitude (Muniz et al., 2014), since UV rays control longitudinal growth, which is influenced by auxins, responsible for regulating stretching in apical regions (Baroniya et al., 2011; Safaralikhonov \& Aknazarov, 2016).

In the 2018/2019 cycle, a significant difference $(p \leq 0.01)$ was found between the training systems for the variables fruit productivity, mass, and diameters in the two cultivation sites (Table 2). In Diamantina, the humid temperate climate region, plant productivity was: $3.91 \mathrm{Mg} \mathrm{ha}^{-1}$ under perennial cultivation in the free system in the second cycle; $1.29 \mathrm{Mg} \mathrm{ha}^{-1}$ under annual cultivation in the free system in the first cycle; $2.14 \mathrm{Mg} \mathrm{ha}^{-1}$ under perennial cultivation in the espalier system in the second cycle; and $2.57 \mathrm{Mg} \mathrm{ha}^{-1}$ under annual cultivation in the espalier system in the first cycle. The results obtained for all training systems did not show a direct relationship between renewal pruning and training system, despite the observed differences, since the productive potential was below that of 13.5 $\mathrm{Mg} \mathrm{ha}^{-1}$ reached by the species in the previous year (Table 1).

The productive performance in the 2018/2019 cycle can be related to the climatic variations that occurred in
Diamantina (Figure 1 B) when plant sprouts underwent renewal pruning and seedlings were planted. After planting and the formation of stems on the pruned plants, in October 2018, there was a hailstorm, with strong gusts of wind, atypical in the region, which caused the plants to fall, damaging the leaf area. This significantly slowed physalis growth at the cultivation site. In addition, from the beginning of the 2018/2019 cycle until the second fertilization, between October and December, the accumulated rainfall was of $385.4 \mathrm{~mm}$ in Diamantina (Figure $1 \mathrm{~B}$ ), whose soil contains $83 \%$ sand, which probably caused a greater leaching of the nutrients applied through fertilization.

Regarding fruit size, that of the plants under perennial cultivation in the second cycle, both in the free and espalier systems, was larger (Table 2). In relation to the mass and diameter of the fruits, the obtained results suggest that the plants in the first production cycle suffered more serious damage due to climatic variations in the growing site, possibly because of their smaller root system for the absorption of nutrients during the period of frequent rains. However, in general, the size of the fruits was not seriously impaired, since the values obtained for mass and both diameters were close

Table 2. Summary of the analysis of variance with its significance and averages for fruit productivity, mass, longitudinal diameter, and transversal diameter of physalis (Physalis peruviana), in the 2018/2019 cycle, grown in two training systems, espalier and free, and in two cultivation cycles, perennial and annual, in the municipalities of Diamantina and Couto de Magalhães de Minas, in the state of Minas Gerais, Brazil.

\begin{tabular}{|c|c|c|c|c|}
\hline \multirow[b]{2}{*}{ Source of variation } & \multicolumn{4}{|c|}{ Medium squares } \\
\hline & $\begin{array}{l}\text { Fruit productivity } \\
\left(\mathrm{Mg} \mathrm{ha}^{-1}\right)\end{array}$ & $\begin{array}{l}\text { Mass } \\
(\mathrm{g})\end{array}$ & $\begin{array}{l}\text { Longitudinal diameter } \\
\qquad(\mathrm{mm})\end{array}$ & $\begin{array}{l}\text { Transversal diameter } \\
(\mathrm{mm})\end{array}$ \\
\hline Training systems in Diamantina & $7.26^{* *}$ & $0.22 * *$ & $13.01 * *$ & $13.15^{* *}$ \\
\hline \multirow[t]{2}{*}{ Training systems in Couto de Magalhães de Minas } & $24.19 * *$ & $0.16^{*}$ & $4.35^{* *}$ & $4.76^{* *}$ \\
\hline & \multicolumn{4}{|c|}{ Averages - cultivation cycle and training systems in Diamantina ${ }^{(1)}$} \\
\hline Perennial free system & $3.91 \mathrm{~A}$ & $2.7 \mathrm{AB}$ & $16.19 \mathrm{~A}$ & $16.31 \mathrm{~A}$ \\
\hline Perennial espalier system & $2.14 \mathrm{C}$ & $2.9 \mathrm{~A}$ & $15.36 \mathrm{~A}$ & $15.78 \mathrm{~A}$ \\
\hline Annual free system & $1.29 \mathrm{D}$ & $2.1 \mathrm{C}$ & 13.03B & $13.07 \mathrm{C}$ \\
\hline Annual espalier system & 2.57BC & 2.3B & 13.63B & 14.22B \\
\hline \multirow[t]{2}{*}{ Coefficient of variation (\%) } & 15.5 & 6.1 & 5.1 & 4.5 \\
\hline & \multicolumn{4}{|c|}{ Averages - cultivation cycle and training systems in Couto de Magalhães de Minas ${ }^{(1)}$} \\
\hline Perennial free system & $2.4 \mathrm{C}$ & $2.0 \mathrm{~B}$ & 14.18B & 14.33B \\
\hline Perennial espalier system & $5.6 \mathrm{AB}$ & $2.2 \mathrm{AB}$ & $15.57 \mathrm{~A}$ & $15.74 \mathrm{~A}$ \\
\hline Annual free system & $5.3 \mathrm{~B}$ & $2.3 \mathrm{AB}$ & $15.75 \mathrm{~A}$ & $16.06 \mathrm{~A}$ \\
\hline Annual espalier system & $8.0 \mathrm{~A}$ & $2.4 \mathrm{~A}$ & $16.14 \mathrm{~A}$ & $16.33 \mathrm{~A}$ \\
\hline Coefficient of variation $(\%)$ & 9.4 & 6.8 & 5.3 & 4.5 \\
\hline
\end{tabular}

(1) Means followed by equal letters, in the columns, do not differ by Tukey's test, at $5 \%$ probability. ** and *Significant at 1 and $5 \%$ probability, respectively, by the F-test. ${ }^{\text {ns Nonsignificant. }}$ 
to those reported in other cultivation sites (Muniz et al., 2011; Moura et al., 2016).

In the 2018/2019 cycle, the plants in the highaltitude tropical climate in Couto de Magalhães de Minas showed the highest yields of $8.0 \mathrm{Mg} \mathrm{ha}^{-1}$ under annual cultivation in the espalier system, compared with that of $5.6 \mathrm{Mg} \mathrm{ha}^{-1}$ under perennial cultivation, also in the espalier system. The obtained results show that the perennial cultivation in the second production cycle reached a productivity that is interesting for producers, from an economic point of view, as it is not necessary to spend on soil preparation and liming. However, pruning management is essential for plant training, considering that, in the free system, without pruning, the achieved productivity was only 2.4 $\mathrm{Mg} \mathrm{ha}^{-1}$ (Table 2), lower than that of the plants in the first year of production in this same site. Although pruning management has been dispensed in some cultivation sites due the consequent reductions in productivity (Moura et al., 2016; D’Angelo et al., 2017), the results observed in the present study are indicative that pruning management contributed to increasing physalis productivity and fruit size, particularly under perennial cultivation up to the second production cycle, in climatic conditions favorable to plant growth.

\section{Conclusions}

1. Physalis (Physalis peruviana) cultivation in humid temperate climate regions with mild temperatures favors high yields and large fruit sizes.

2. The training system in espalier with formation pruning facilitates plant management and increases productivity.

3. The viability of the perennial cultivation of physalis varies according to the climatic conditions of the cultivation site and the training system adopted.

\section{Acknowledgments}

To Coordenação de Aperfeiçoamento de Pessoal de Nível Superior (Capes), for partial financing (Finance Code 001); and to Universidade Federal dos Vales do Jequitinhonha e Mucuri (UFVJM), for providing the infrastructure needed to conduct the study.

\section{References}

AGRITEMPO: sistema de monitoramento agrometeorológico: [estado de MG]. Available at: <https://www.agritempo.gov.br/ agritempo/jsp/PesquisaClima/index.jsp?siglaUF $=\mathrm{MG}>$. Accessed on: July 302019.

APARECIDO, L.E. de O.; BATISTA, R.M.; MORAES, R. da S.C. de; COSTA, C.T.S.; MORAES-OLIVEIRA, A.F. de. Agricultural zoning of climate risk for Physalis peruviana cultivation in Southeastern Brazil. Pesquisa Agropecuária Brasileira, v.54, e00057, 2019. DOI: https://doi.org/10.1590/S1678-3921.pab2019. v54.00057.

BARONIYA, S.S.; KATARIA, S.; PANDEY, G.P.; GURUPRASAD, K.N. Intraspecific variation in sensitivity to ambient ultraviolet-B radiation in growth and yield characteristics of eight soybean cultivars grown under field conditions. Brazilian Journal of Plant Physiology, v.23, p.197-202, 2011. DOI: https://doi.org/10.1590/S1677-04202011000300003.

BOLZAN, R.P.; CUQUEL, F.L.; LAVORANTI, O.J. Armazenamento refrigerado de Physalis. Revista Brasileira de Fruticultura, v.33, p.577-583, 2011. DOI: https://doi.org/10.1590/ S0100-29452011000500079.

BRAGA NETO, A.M.; SILVA, E. de B.; CRUZ, M. do C.M. da; LAGE, P.; GONÇALVES, E.D.; SILVA, L.F.O.; LIMA, R.C.; SANTOS, V.K.S. Response of physalis (Physalis peruviana L.) to liming in acidic soils. Australian Journal of Crop Science, v.13, p.2038-2045, 2019. DOI: https://doi.org/10.21475/ajcs.19.13.12. p2058.

CODEX ALIMENTARIUS. Codex STAN 226: norma para la uchuva (Codex STAN 226-2001). Rome: FAO, 2011.

CRIOLlO, H.; LAGOS, T.C.; FISCHER, G.; MORA, L.; ZAMUDIO, LADY. Comportamiento de tres genotipos de uchuva (Physalis peruviana L.) bajo diferentes sistemas de poda. Revista

Colombiana de Ciencias Hortícolas, v.8, p.34-43, 2014. DOI: https://doi.org/10.17584/rcch.2014v8i1.2798.

D’ANGELO, J.W. de O.; BASTOS, M.C.; CUQUEL, F.L. Maintenance pruning in physalis commercial production. Bragantia, v.76, p.214-219, 2017. DOI: https://doi.org/10.1590/1678-4499.128.

FERREIRA, D.F. Sisvar: a guide for its bootstrap procedures in multiple comparisons. Ciência e Agrotecnologia, v.38, p.109-112, 2014. DOI: https://doi.org/10.1590/S1413-70542014000200001.

FISCHER, G.; ALMANZA-MERCHÁN, P.J.; MIRANDA, D. Importancia y cultivo de la uchuva (Physalis peruviana L.). Revista Brasileira de Fruticultura, v.36, p.1-15, 2014. DOI: https://doi.org/10.1590/0100-2945-441/13.

FISCHER, G.; ALMANZA-MERCHÁN, P.J.; RAMÍREZ, F. Source-sink relationships in fruit species: a review. Revista Colombiana de Ciencias Hortícolas, v.6, p.238-253, 2012. DOI: https://doi.org/10.17584/rcch.2012v6i2.1980.

LIMA, C.S.M.; GALARÇA, S.P.; BETEMPS, D.L.; RUFATO, A. de R.; RUFATO, L. Avaliação física, química e fitoquímica de frutos de Physalis, ao longo do período de colheita. Revista 
Brasileira de Fruticultura, v.34, p.1004-1012, 2012. DOI: https://doi.org/10.1590/S0100-29452012000400006.

MOURA, P.H.A.; COUTINHO, G.; PIO, R.; BIANCHINI, F.G.; CURI, P.N. Plastic covering, planting density, and prunning in the production of cape gooseberry (Physalis peruviana L.) in subtropical region. Revista Caatinga, v.29, p.367-374, 2016. DOI: https://doi.org/10.1590/1983-21252016v29n213rc.

MUNIZ, J.; KRETZSCHMAR, A.A.; RUFATO, L.; PELIZZA, T.R.; MARCHI, T.; DUARTE,A.E.; LIMA,A.P.F.; GARANHANI, F. Sistemas de condução para o cultivo de physalis no planalto catarinense. Revista Brasileira de Fruticultura, v.33, p.830-838, 2011. DOI: https://doi.org/10.1590/S0100-29452011005000083.

MUNIZ, J.; KRETZSCHMAR, A.A.; RUFATO, L.; PELIZZA, T.R.; RUFATO, A.D.R.; MACEDO, T.A. de. General aspects of physalis cultivation. Ciência Rural, v.44, p.964-970, 2014. DOI: https://doi.org/10.1590/S0103-84782014005000006.

MUNIZ, J.; MARCHI, T.; COLDEBELLA, M.C.; RUFATO, L.; KRETZSCHMAR, A.A. Crescimento vegetativo e potencial produtivo de fisális. Revista de Ciências Agroveterinárias, v.14, p.15-23, 2015a.

MUNIZ, J.; MOLINA, A.R.; MUNIZ, J. Physalis: panorama produtivo e econômico no Brasil. Horticultura Brasileira, v.33, 2015b. DOI: https://doi.org/10.1590/S0102-053620150000200023.
PIMENTEL-GOMES, F.; GARCIA, C.A. Estatística aplicada a experimentos agronômicos e florestais: exposição com exemplos e orientações para uso de aplicativos. Piracicaba: Fealq, 2002. 309p.

RODRIGUES, F.A.; PENONI, E. dos S.; SOARES, J.D.R.; SILVA, R.A.L.; PASQUAL, M. Caracterização física, química e físicoquímica de physalis cultivada em casa de vegetação. Ciencia Rural, v.44, p.1411-1414, 2014. DOI: https://doi.org/10.1590/0103$8478 \mathrm{cr} 20130743$.

RUFATO, L.; MUNIZ, J.; KRETZSCHMAR, A.A.; RUFATO, A. de R.; GATIBONI, L.C. Aspectos técnicos da cultura da fisalis. Informe Agropecuário, v.33, p.69-83, 2012.

SAFARALIKHONOV, A.; AKNAZAROV, O. The dynamics of endegenous hormone activity in plant leaves depending on the altitude of their growing. Social and Natural Sciences Journal, v.10, p.9-14, 2016. DOI: https://doi.org/10.12955/snsj.v10i2.886.

SANTOS, H.G. dos; JACOMINE, P.K.T.; ANJOS, L.H.C. dos; OLIVEIRA, V.Á. de; LUMBRERAS, J.F.; COELHO, M.R.; ALMEIDA, J.A. de; ARAÚJO FILHO, J.C. de; OLIVEIRA, J.B. de; CUNHA, T.J.F. Sistema brasileiro de classificação de solos. 5.ed. rev. e ampl. Brasília: Embrapa, 2018. 